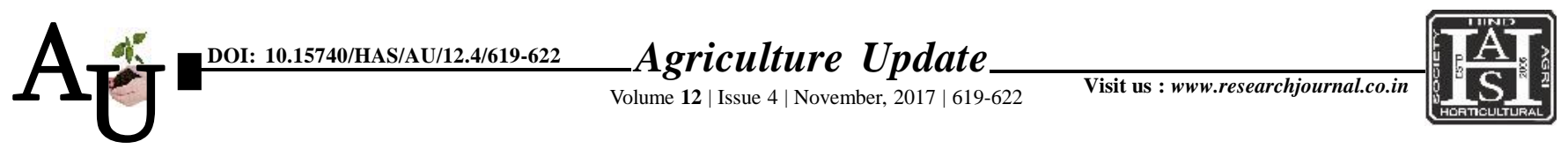

a e ISSN-0976-6847

\title{
Research article: Knowledge of recommended lime cultivation practices
}

\section{JAMEER R. ATTAR AND S.G. ASKI}

Article Chronicle :

Received :

06.09.2017;

Revised :

12.09.2017;

Accepted :

29.09.2017

KeY Words :

Knowledge, Citrus

fruits, Lime growers
SUMMARY : Fruit growing or pomology is of special value in the industrialization of a country and it serves as the mother of many industries because it is as old as human civilization itself. Fruits are man's oldest food and are the chief source of vitamins, minerals and proteins which are necessary to maintain proper health and acquire resistance to diseases. Kagzi lime (Citrus aurantifolia Swingle) is cultivated extensively on commercial scale and is more popular than lemon. The present investigation was conducted in Vijayapura and Kalaburagi district of Northern Karnataka in the year 2013-14. A sample size of 140 respondents who have minimum one acre of lime orchard and who have at least five years and above old orchard were selected randomly. The data were collected through personal interview method with the help of structured interview schedule. indicated that majority of the lime growers had correct knowledge of recommended varieties, suitable soil, plant spacing, ideal size of pit, fertilizer application and irrigation method, majority (53.58 \%) of lime growers had medium knowledge level followed by high $(30.71 \%)$ and low $(15.71 \%)$ level of knowledge.

How to cite this article : Attar, Jameer R. and Aski, S.G. (2017). Knowledge of recommended lime cultivation practices. Agric. Update, 12(4): 619-622; DOI : 10.15740/HAS/AU/12.4/619-622.

\section{Author for correspondence :}

\section{S.G. ASKI}

Department of Agricultural Extension Education, College of Agriculture (UAS), VIJAYAPURA (KARNATAKA) INDIA Email : askisubhash@ gmail.com

See end of the article for authors' affiliations 